\title{
The effect of dietary supplementation with globin and spray- dried porcine plasma on performance, digestibility and histomorphological traits in broiler chickens
}

\author{
Sihem Dabbou ${ }^{1,2}$ (D) | Angela Trocino ${ }^{3}$ (D) | Gerolamo Xiccato4 ${ }^{4}$ (D) | Joana Nery ${ }^{5}$ (D) \\ Josefa Madrid $^{6}$ (D) | Silvia Martinez ${ }^{6}$ (D) | Fuensanta Hernández ${ }^{6}$ (D) | Isabelle D. Kalmar ${ }^{7}$ (D) \\ Maria Teresa Capucchio ${ }^{5,8}$ (D) | Elena Colombino ${ }^{5}$ (D) | |laria Biasato ${ }^{9}$ (D) | Lucia Bailoni ${ }^{3}$ (D) \\ Laura Gasco $^{9}$ (D) | Cecilia Mugnai ${ }^{5}$ (D) | Achille Schiavone ${ }^{5,8}$ (i)
}

${ }^{1}$ Center Agriculture Food Environment (C3A), University of Trento, San Michele all'Adige, Italy

${ }^{2}$ Research and Innovation Centre, Fondazione Edmund Mach, San Michele all'Adige, Italy

${ }^{3}$ Department of Comparative Biomedicine and Food Science, University of Padua, Padua, Italy

${ }^{4}$ Department of Agronomy, Food Natural Resources, Animals and Environment (DAFNAE), University of Padua, Padua, Italy

${ }^{5}$ Department of Veterinary Sciences, University of Turin, Grugliasco, Italy

${ }^{6}$ Department of Animal Production, University of Murcia, Murcia, Spain

${ }^{7}$ Veos, Zwevezele, Belgium

${ }^{8}$ Institute of Science of Food Production, National Research Council, Turin, Italy

${ }^{9}$ Department of Agricultural, Forest and Food Sciences, University of Turin, Turin, Italy

\section{Correspondence}

Joana Nery, Department of Veterinary Sciences, University of Turin, Largo Paolo Braccini 2, 10095 Grugliasco (TO), Italy. Email: joana.nery@unito.it

Funding information

VEOS, Grant/Award Number: SCHA CONTR_FIN_18_01

\begin{abstract}
This study evaluated the effects of globin and spray-dried porcine plasma (SDPP) on growth performance, digestibility, nitrogen retention, energy retention efficiency (ERE) and intestinal morphology of broiler chickens. A total of 336-day-old male broiler chickens were reared from 1 to 40 days of age and fed 3 diets ( 8 replicates/diet, 14 birds/replicate) during 3 feeding phases: starter (1-12 days), grower (12-25 days) and finisher (25-40 days). Isonitrogenous diets were formulated by replacing gluten protein isolate contained in the control diet ( $\mathrm{C}$ diet) with $2 \%$ (starter) or $1 \%$ (grower and finisher) spray-dried porcine plasma in the plasma diet (SDPP diet). The globin diet ( $G$ diet) was obtained by adding globin on the top of $C$ diet at a dose of $0.08 \%$ for the whole rearing period. Total tract apparent digestibility $(\mathrm{aD})$, nitrogen retention and ERE were assessed during the three growing phases. At 12 and 40 days of age, one bird per pen was slaughtered to sample gut, liver, spleen and bursa of Fabricius for histomorphological investigations. The SDPP diet increased body weights of chickens at 12 (+60 g; $p<.001), 25$ (+101 g; $p<.001)$ and 40 days (+130 g; $p=.018$ ) of age compared to $C$ and $G$ diets. Also SDPP improved crude protein $a D(+9.7 \%)$ and ERE $(+12.3 \%)$ during the starter phase $(p<.001)$. Dietary globin and SDPP inclusion did not affect either the gut morphology or the histopathological findings in birds at 12 and 40 days of age, despite a numerical ( $+6.90 \%$ and $+7.40 \%$ respectively) villus height improvement in the SDPP group. Overall, these results confirm that dietary supplementation with SDPP and, to a lesser extent, with globin can improve growth performance and dietary protein and energy utilization in broiler chickens without effect on gut functionality.
\end{abstract}

KEYWORDS

blood by-products, broiler chickens, digestibility, histomorphology, performance 


\section{1 | INTRODUCTION}

Some protein sources can provide benefits in terms of improved animal health and productive performance, which can reduce the use of antimicrobials. Among these feedstuffs, processed blood by-products obtained from slaughterhouses, such as globin and spray-dried porcine plasma (SDPP), can be used in the diets for broiler chickens (Beski, Swick, \& lji, 2015a; Boyer et al., 2015; Dabbou et al., 2019).

The SDPP is considered a high quality protein source with functional properties (Henn et al., 2013); it contains approximately $78 \%$ crude protein (CP) with high levels of essential amino acids (AA), such as lysine, tryptophan and threonine (Stein, 1996). It has been found to increase the surface area of villi and thus intestinal absorptive function, which may improve feed efficiency and nutrient utilization (Thomson, Jones, \& Eisen, 1995). In piglets, SDPP has been used as a source of highly digestible and palatable protein in starter diets, to increase protection against enteric infections and to enhance intestinal development over the stressful weaning period (Coffey \& Cromwell, 2001; van Dijk, Everts, Nabuurs, Margry, \& Beynen, 2001; Müller et al., 2018; Pérez-Bosque, Polo, \& Torrallardona, 2016; Torrallardona, 2010). In poultry diets, SDPP improved nutrient digestibility (Campbell, Quigley, Russel, \& Kidd, 2003) as well as growth performance of broilers and turkeys raised under bad sanitary conditions (Campbell, Quigley, \& Russel, 2004; Campbell et al., 2003). Jamroz, Wiliczkiewicz, Orda, Kuryszko, and Stefaniak, (2012) also showed that SDPP was as effective as soybean meal in increasing the body weight of broilers and enhancing sodium and potassium retention.

Globin is produced by hydrolysis of porcine haemoglobin into haem and globin, and is considered as a protein-based emulsifier that acts in the duodenum and jejunum (Arnouts \& Lippens, 2006; Dabbou et al., 2019). Emulsifiers act synergistically with natural bile salts in the animal's gut to favour fat digestion and absorption. They increase the active surface of fats, allowing the action of lipases that hydrolyze triglyceride molecules into fatty acids and monoglycerides, and favour the formation of micelles consisting of lipolysis products. Previous studies showed that the dietary supplementation with globin significantly improved feed conversion ratio (FCR) between 10 and 42 days of age (Arnouts \& Lippens, 2006). Recently, also Dabbou et al. (2019) found that the addition of $0.05 \%$ globin to broiler chicken diets decreased FCR and increased fat digestibility, protein metabolism, protein efficiency ratio and net energy for production during the starter phase.

Based on the above-mentioned studies, the inclusion of SDPP and globin in broiler chickens has been found to affect growth performance, but the biological mechanisms underlying these effects have not been fully elucidated whereas an effect on the physiological intestinal development and morphology, and on the health status of the gut has been hypothesized. Therefore, the purpose of this study was to assess the effects of the dietary inclusion of SDPP and globin on growth performance, digestibility, nitrogen retention, energy retention efficiency, intestinal morphology and histological traits of broiler chickens throughout the starter, grower and finisher phases.

\section{2 | MATERIALS AND METHODS}

The trial was performed by the Department of Veterinary Sciences (DVS) of the University of Turin (Italy) in collaboration with a commercial poultry house located in Airasca (TO, Italy). The experimental protocol was approved by the Ethical Committee for Animal Experimentation of the DVS (Protocol no. 420078). All animals were handled in respect to the principles stated by the EC Directive $86 / 609 /$ EEC regarding the protection of animals used for experimental and other scientific purposes.

\section{1 | Birds and husbandry}

A total of 336 one-day-old male broiler chicks (ROSS 308, Aviagen) were randomly allotted to 3 dietary treatments for a 40-days rearing cycle. Each dietary group consisted of 8 pens, as replicates, with 14 chicks per pen. The pens were $1.20 \mathrm{~m}$ wide $\times 1.20 \mathrm{~m}$ long, with rice hulls as litter. Feed and drinking water were distributed ad libitum in hanging feeders (1/pen) and automatic water dispensers (4/pen). The poultry house was equipped with automatic ventilation, infrared lamps and controlled light systems. The birds were individually identified using a wing mark, applied at their arrival. Twenty-three hours of light were provided during the first three days; afterwards, light hours were progressively reduced until a 18L:6D light program. All chicks were vaccinated against Infectious Bronchitis, Gumboro disease and Newcastle disease at the hatchery.

\begin{tabular}{|c|c|c|c|c|c|c|c|c|c|}
\hline & \multicolumn{3}{|c|}{ Starter phase } & \multicolumn{3}{|c|}{ Grower phase } & \multicolumn{3}{|c|}{ Finisher phase } \\
\hline & $\begin{array}{l}\text { C } \\
\text { diet }\end{array}$ & G diet & $\begin{array}{l}\text { SDPP } \\
\text { diet }\end{array}$ & $\begin{array}{l}\text { C } \\
\text { diet }\end{array}$ & G diet & $\begin{array}{l}\text { SDPP } \\
\text { diet }\end{array}$ & $\begin{array}{l}\text { C } \\
\text { diet }\end{array}$ & G diet & $\begin{array}{l}\text { SDPP } \\
\text { diet }\end{array}$ \\
\hline \multicolumn{10}{|c|}{ Ingredient (\% as fed) } \\
\hline GP & 2.00 & 2.00 & - & 1.00 & 1.00 & - & 1.00 & 1.00 & - \\
\hline G & - & 0.08 & - & - & 0.08 & - & - & 0.08 & - \\
\hline SDPP & - & - & 2.00 & - & - & 1.00 & - & - & 1.00 \\
\hline
\end{tabular}

TABLE 1 The schedule of the feeding trial

Abbreviations: C, control; G, globin; GP, gluten protein; SDPP, spray-dried porcine plasma. 


\section{2 | Experimental diets}

The experimental diets were prepared at the experimental facility of the Department of Agricultural, Forest and Food Science of the University of Turin. The ingredients were individually weighed and subsequently mixed in order to obtain crumble pelleted diets.

Three experimental diets were used, control (C diet), globin (G diet) and spray-dried porcine plasma (SDPP diet) (Tables 1 and 2). The SDPP diet was formulated by replacing the gluten protein isolate (lysine $1.83 \%$; methionine $1.50 \%$; threonine $2.40 \%$; valine $4.30 \%$; arginine $3.30 \%$; glycine $2.90 \%$; phenylalanine $4.73 \%$; and cystine $2.02 \%$ on dry matter [DM] basis) in the $\mathrm{C}$ diet with spray-dried porcine plasma at a dose of $2 \%$ in the starter diet and $1 \%$ in the grower and finisher diets (SDPP, Actipro ${ }^{\circledR}$ 85PPS, Veos, Belgium; 94\% DM; 13.1 MJ metabolizable energy (ME)/kg as is; $85 \%$ CP; $2 \%$ fat; lysine 4.04\%; methionine $0.78 \%$; threonine $3.10 \%$; tyrosine $4.37 \%$; valine $6.85 \%$; arginine $3.83 \%$; glycine $4.58 \%$; phenylalanine $7.42 \%$; and cystine $3.28 \%$ on DM basis) (Table 1). The $G$ diet was obtained by topping the $\mathrm{C}$ diet with globin, at a dose of $0.08 \%$ (Globin, Actipro ${ }^{\circledR}$ 95PGS, Veos, Belgium; 93\% DM; $14.4 \mathrm{MJ} \mathrm{ME/kg} \mathrm{as} \mathrm{is;} 92 \% \mathrm{CP}$;
TABLE 2 Ingredients of the experimental diets (\% as fed)

\begin{tabular}{|c|c|c|c|c|c|c|}
\hline \multirow{2}{*}{$\begin{array}{l}\text { Periods on trial } \\
\text { Diets }\end{array}$} & \multicolumn{2}{|c|}{ Starter phase } & \multicolumn{2}{|c|}{ Grower phase } & \multicolumn{2}{|c|}{ Finisher phase } \\
\hline & $\begin{array}{l}\text { C and G } \\
\text { diets }^{\mathrm{a}}\end{array}$ & $\begin{array}{l}\text { SDPP } \\
\text { diet }\end{array}$ & $\begin{array}{l}\text { C and G } \\
\text { diets }^{\mathrm{a}}\end{array}$ & $\begin{array}{l}\text { SDPP } \\
\text { diet }\end{array}$ & $\begin{array}{l}\text { C and G } \\
\text { diets }^{\mathrm{a}}\end{array}$ & $\begin{array}{l}\text { SDPP } \\
\text { diet }\end{array}$ \\
\hline Maize meal & 43.085 & 43.085 & 35.000 & 35.000 & 35.000 & 35.000 \\
\hline $\begin{array}{l}\text { Soybean meal }(48 \% \\
\text { CP) }\end{array}$ & 31.567 & 31.567 & 26.720 & 26.720 & 29.902 & 29.902 \\
\hline Wheat meal & 15.000 & 15.000 & 27.536 & 27.536 & 23.571 & 23.571 \\
\hline Soybean oil & 2.307 & 2.307 & 3.192 & 3.192 & 3.000 & 3.000 \\
\hline Extruded soybean & 2.000 & 2.000 & 3.000 & 3.000 & 3.000 & 3.000 \\
\hline Gluten protein (GP) & 2.000 & - & 1.000 & - & 1.000 & - \\
\hline $\begin{array}{l}\text { Spray-dried porcine } \\
\text { plasma (SDPP) }\end{array}$ & - & 2.000 & - & 1.000 & - & 1.000 \\
\hline Dicalcium phosphate & 1.273 & 1.273 & 0.915 & 0.915 & 1.973 & 1.973 \\
\hline Calcium carbonate & 0.576 & 0.576 & 0.595 & 0.595 & 0.694 & 0.694 \\
\hline $\begin{array}{l}\text { Trace mineral-vitamin } \\
\text { premix }^{\text {b }}\end{array}$ & 0.500 & 0.500 & 0.493 & 0.493 & 0.634 & 0.634 \\
\hline L-Lysine $\mathrm{HCl}$ & 0.479 & 0.479 & 0.400 & 0.400 & 0.282 & 0.282 \\
\hline DL-methionine ${ }^{c}$ & 0.335 & 0.335 & 0.338 & 0.338 & 0.191 & 0.191 \\
\hline Sodium chloride & 0.237 & 0.237 & 0.250 & 0.250 & 0.180 & 0.180 \\
\hline L-Threonine & 0.150 & 0.150 & 0.131 & 0.131 & 0.180 & 0.180 \\
\hline Sodium bicarbonate & 0.131 & 0.131 & 0.100 & 0.100 & 0.100 & 0.100 \\
\hline Optifos 250 Bro $^{d}$ & 0.100 & 0.100 & 0.100 & 0.100 & 0.100 & 0.100 \\
\hline Avizyme $1500 x^{e}$ & 0.100 & 0.100 & 0.100 & 0.100 & 0.083 & 0.083 \\
\hline Choline & 0.100 & 0.100 & 0.070 & 0.070 & 0.060 & 0.060 \\
\hline Maxiban $^{f}$ & 0.060 & 0.060 & 0.060 & 0.060 & 0.050 & 0.050 \\
\hline AME (MJ/kg DM) & 12.59 & 12.53 & 12.65 & 12.62 & 13.31 & 13.28 \\
\hline Total & 100.00 & 100.00 & 100.00 & 100.00 & 100.00 & 100.00 \\
\hline
\end{tabular}

Abbreviations: AME, apparent metabolisable energy; C, control; CP, crude protein; DM, dry matter; G, globin; GP, gluten protein; SDPP, spray-dried porcine plasma.

${ }^{a} \mathrm{G}$ diet has the same ingredients of $\mathrm{C}$ diet, and globin (as Actipro ${ }^{8}$ 95PGS) was added on top at the dose of $0.08 \%$.

${ }^{\mathrm{b}}$ Mineral-vitamin premix (per kg diet): vitamin A (retinyl acetate), 12,500 IU; vitamin D3 (cholecalciferol), 3,500 IU; vitamin E (DL-a-tocopheryl acetate), $40 \mathrm{mg}$; vitamin $\mathrm{K}$ (menadione sodium bisulphite), $2 \mathrm{mg}$; biotin, $0.20 \mathrm{mg}$; tiamin, $2 \mathrm{mg}$; riboflavin, $6 \mathrm{mg}$; pantothenate, $15.21 \mathrm{mg}$; niacin, 40 mg; choline, $750 \mathrm{mg}$; pyridoxin, $4 \mathrm{mg}$; folic acid, $0.75 \mathrm{mg}$; vitamin B12, $0.03 \mathrm{mg}$; Mn, 70 mg; Zn, 62.15 mg; Fe, 50 mg; Cu, 7 mg; I, 0.25 mg; Se, 0.25 mg.

${ }^{\mathrm{C} D L-m e t h i o n i n e: ~ a n a l o g o u s ~ h y d r o x y ~ m e t h i o n i n e ~(R h o d i m e t ~ A T 88, ~ A d i s s e o, ~ A n t o n y, ~ F r a n c e) . ~}$ ${ }^{\mathrm{d} O p t i f o s} 250$ Bro (Huvepharma, Sofia, Bulgaria): Phytase (EC 3.1.3.26), 250 OTU/kg diet. ${ }^{\mathrm{e}}$ Avizyme 1500 (Danisco Animal Nutrition, Marlborough, Wiltshire, UK): complex of endo 1-4-beta-xylanase (EC 3.2.1.8) (256 U/kg), subtilisine (Ec 3.4.21.62) (2,560 U/kg diet) and alphaamylase (EC3.2.1.1), 1,472 U/kg diet.

${ }^{f}$ Maxiban (Elanco, Italy): anticoccidial composed of Nicarbazin $80,000 \mathrm{mg} / \mathrm{kg}$ and Narasin $80,000 \mathrm{mg} / \mathrm{kg}$. 
$0.3 \%$ fat; lysine $5.34 \%$; methionine $0.79 \%$; threonine $3.70 \%$; tyrosine $2.27 \%$; valine $3.81 \%$; arginine $3.62 \%$; glycine $2.41 \%$; phenylalanine $3.13 \%$; and cystine $3.37 \%$ on DM basis). Both SDPP and globin supplementation doses were established according to the manufacturer's recommendations. All diets were formulated according to Aviagen (2014) specifications, identifying three different phases: starter (1-12 days), grower (12-25 days) and finisher (25-40 days) (Table 2 and 3 ) and were always provided ad libitum.

\section{3 | Growth performance}

The body weights (BW) of birds were recorded individually at their arrival and at the end of each feeding phase. Average daily feed intake (ADFI), average daily weight gain (ADG) and FCR were calculated for each experimental group within feeding phase and the entire rearing period. Feed intake and all other measurements were performed at pen level. All weighings were performed using electronic scales with an accuracy of $0.1 \mathrm{~g}$ (Signum, Sartorius). During the trial, health was always good and only eight (2.4\%) chickens died (two fed $\mathrm{C}$ diet, four fed $\mathrm{G}$ diet and two fed SDPP diet).

\section{4 | Nutrient Digestibility}

The digestibility trial was performed at the end of the starter phase using titanium dioxide $\left(\mathrm{TiO}_{2} ; 5 \mathrm{~g} / \mathrm{kg}\right.$ diet $)$ as an indigestible marker, which was added during the preparation of the experimental starter diet. The method of Kaczmarek, Bochenek, Samuelsson, and Rutkowski, (2015) was used to estimate the nutrient digestibility, with minor modifications reported by Dabbou et al. (2019). Briefly, excreta were collected for approximately $1 \mathrm{hr}$ per day, for four consecutive days. After collection, the excreta of each pen were pooled and stored at $-20^{\circ} \mathrm{C}$, until freeze-drying and analyses. The apparent nutrient digestibility $(\mathrm{aD})$ was calculated for $\mathrm{CP}$ and ether extract (EE). The uric acid (UA) content in the excreta samples was determined by a spectrophotometer (UNICAN UV-Vis Spectrometry, Helios Gamma, Fisher Scientific Ltd, Loughborough, UK) according to the Marquardt (1983) method. The CP amount of the excreta was corrected (CP corrected) for UA nitrogen as follows:

$$
\text { CPcorrected }=\left([N]_{\text {Kjeldahl }}-[N]_{\text {uric acid }}\right) \times 6.25
$$

To calculate the digestibility coefficients, the titanium dioxide contents of feed and freeze-dried excreta were measured by the colorimetric method described by Myers, Ludden, Nayigihugu, and Hess, (2004). The apparent digestibility $(\mathrm{aD})$ of each nutrient $(X)$ was calculated as follows:

$$
\mathrm{aD} X(\%)=\left(1-\frac{\left[\mathrm{TiO}_{2}\right] \text { diet } \times[\text { nutrient } \mathrm{X}] \text { excreta }}{\left[\mathrm{TiO}_{2}\right] \text { excreta } \times[\text { nutrient } \mathrm{X}] \text { diet }}\right) \times 100
$$

where [nutrient $X$ ]diet and [nutrient $X$ ] excreta are the measured contents of the nutrients $(X)$ in the diets and excreta $(g / k g)$, respectively, and $\left[\mathrm{TiO}_{2}\right]$ diet and $\left[\mathrm{TiO}_{2}\right]$ excreta are the measured contents of titanium dioxide in the diet and excreta $(\mathrm{g} / \mathrm{kg})$, respectively. Nitrogen retention was calculated using the digestibility formula and considering the excreta total CP.

\section{5 | Slaughtering and sampling}

A total of 56 chickens ( 8 birds at 1 day, 24 birds at 12 day and 24 birds at 40 day of age) were sacrificed by intravenous injection of pentobarbital sodium in the wing vein, and the whole body was stored to determine the whole-body energy. Further 48 chickens (24 birds at

\begin{tabular}{|c|c|c|c|c|c|c|c|c|c|}
\hline Diets & \multicolumn{3}{|c|}{ Starter phase } & \multicolumn{3}{|c|}{ Grower phase } & \multicolumn{3}{|c|}{ Finisher phase } \\
\hline $\mathrm{DM}, \%$ & 91.3 & 91.4 & 92.0 & 91.3 & 91.6 & 91.3 & 92.0 & 91.6 & 91.2 \\
\hline Ash, \% DM & 5.64 & 6.26 & 5.65 & 5.72 & 5.08 & 5.04 & 4.42 & 4.22 & 4.91 \\
\hline $\mathrm{CP}, \% \mathrm{DM}$ & 23.7 & 25.0 & 24.0 & 23.2 & 23.4 & 24.0 & 21.2 & 20.1 & 21.2 \\
\hline $\mathrm{EE}, \% \mathrm{DM}$ & 5.72 & 5.94 & 6.01 & 5.88 & 5.18 & 5.17 & 6.93 & 6.23 & 7.11 \\
\hline NFE, \% DM & 62.4 & 60.4 & 61.8 & 62.2 & 63.2 & 62.5 & 64.4 & 66.5 & 63.6 \\
\hline $\begin{array}{l}\text { Sugar + starch, \% } \\
\text { DM }\end{array}$ & 45.3 & 44.4 & 43.4 & 44.5 & 46.0 & 46.9 & 46.7 & 50.4 & 46.2 \\
\hline GE, MJ/kg DM & 18.96 & 18.94 & 18.81 & 18.81 & 18.75 & 18.81 & 18.97 & 19.09 & 19.16 \\
\hline
\end{tabular}

TAB LE 3 Analysed chemical composition of experimental diets during the rearing periods

Abbreviations: C, control; CF, crude fibre; CP, crude protein; DM, dry matter; EE, ether extract; G, globin; GE, gross energy; NFE, nitrogen-free extract; SDPP, spray-dried porcine plasma. 
12 day and 24 at 40 day of age) were slaughtered to sample organs for histomorphological investigations.

\subsection{Analyses of diets, excreta and whole body}

Diets and freeze-dried excreta were ground through a 1-mm screen (Retsch ZM 200 Ultra Centrifugal Mill, Retsch). The DM content was determined by drying the samples at $103^{\circ} \mathrm{C}$ to constant weight. Ash content was determined by muffle furnace incineration (942.05), $\mathrm{CP}(\mathrm{N} \times 6.25)$ was measured with Kjeldahl method (2001.11), crude fibre (CF) was determined after sulphuric acid treatment (962.09 method) and EE by ether extraction (920.39) according to the AOAC (2005) standard procedures. The nitrogen-free extract (NFE) was calculated as follow: NFE\% $=[\mathrm{DM}-($ Ash\% $+\mathrm{CP} \%+\mathrm{EE} \%+\mathrm{CF} \%)]$, whereas the content of sugar + starch was measured polarimetrically (BOE, 2000). The gross energy (GE) content was determined using an adiabatic calorimetric bomb (C7000, IKA).

For the determination of amino acids contents in feed supplements (Globin, SDPP and gluten protein) and diets, the samples were hydrolysed with $6 \mathrm{~N} \mathrm{HCl}$ for $22 \mathrm{hr}$ at $112^{\circ} \mathrm{C}$ under nitrogen atmosphere. In the case of methionine and cystine, performic acid oxidation occurred prior to acid hydrolysis. The amino acids in hydrolysate were performed by HPLC (Waters) after post-column derivatization using the procedure indicated by Madrid et al. (2013).

The bodies of the chickens slaughtered at 0,12 and 40 days of age were minced, homogenized and freeze-dried. Then, samples were used to determine the whole-body energy ( $\mathrm{GE}_{\mathrm{bird}}, \mathrm{MJ} / \mathrm{bird}$ ) according to Fatufe, Timmler, and Rodehutscord, (2004) by adiabatic calorimetric bomb.

\subsection{Calculation of Energy Retention Efficiency}

The difference between $\mathrm{GE}_{\text {bird }}$ at 12 and 0 days, at 40 and 12 days and at 40 and 0 days of age defined energy accretion (EA) during each phase (starter, grower and whole rearing periods). The GE intake was given by the product of $\mathrm{FI}$ and GE of diet during each growth phase. The energy retention efficiency (ERE, \%) was calculated as the ratio between EA and GE intake during each growing phase, as reported by Dabbou et al. (2019), being dy and $d x$ the final and first day of each period respectively.

$$
\operatorname{ERE}(\%)=\frac{E A}{G_{\text {intake }}}=\frac{\mathrm{GE}_{\text {bird dy }}-\mathrm{GE}_{\text {bird dx }}}{(\mathrm{FI}(\mathrm{dy}-\mathrm{dx})) * \mathrm{GE}_{\text {diet }}}
$$

\section{8 | Histomorphological investigations}

A total of 48 birds were slaughtered at 12 and 40 days of age ( 8 animals per group per age and 1 animal per pen per age) and submitted to histomorphological investigations. Intestinal samples (approximately $5 \mathrm{~cm}$ in length) of duodenum (the duodenal loop), jejunum (the portion before the Meckel's diverticulum) and ileum (the tract before the ileocolic junction) were excised and flushed with $0.9 \%$ saline to remove the digesta. Samples of liver, spleen and bursa of Fabricius were also collected. Gut segments were fixed in Carnoy's solution for morphometric analysis, whereas the samples of other organs were fixed in a $10 \%$ buffered formalin solution for histopathological examination. Tissues were routinely processed, embedded in paraffin wax blocks, sectioned at $5 \mu \mathrm{m}$ thickness, mounted on glass slides, stained with haematoxylin and eosin and examined by light microscopy. A total of three serial sections were prepared for each intestinal segment, and the same slide among the serial sections was considered for morphometric analyses. In particular, 10 well-oriented and intact villi and 10 crypts, selected from duodenum, jejunum and ileum, were measured per each bird (Qaisrani et al., 2014). The evaluated morphometric indices were the villus height ( $\mathrm{Vh}$, from the tip of the villus to the crypt), the crypt depth ( $\mathrm{Cd}$, from the base of the villus to the submucosa) and their ratio (Vh/Cd) (Laudadio et al., 2012). A total of three serial sections were prepared for each sampled organ too, with the most representative one per bird being considered for the histopathological examination. In particular, the following histopathological alterations were evaluated: hepatocyte degeneration and lymphoid tissue activation in the liver, white pulp hyperplasia or depletion in the spleen, and follicular depletion in the bursa of Fabricius. The observed histopathological alterations were assessed using a semiquantitative scoring system as follows: absent (score $=0$ ), mild (score $=1$ ), moderate (score $=2$ ) and severe (score $=3$ ) as detailed by Biasato et al. (2017) and Dabbou et al. (2018). The slides were blinded evaluated by three different observers and the discordant cases were reviewed using a multi-head microscope until an unanimous consensus was reached.

\section{9 | Statistical analysis}

The statistical analysis of data was performed using the IBM SPSS software package (IBM Corp. Released 2012. IBM SPSS Statistics for Windows, version 21.0. IBM Corp).

The experimental unit was the pen for growth performance and apparent nutrient digestibility and the bird for gut morphometric indices and organ histopathological traits. The assumption of equal variances was assessed by Levene's homogeneity of variance test. Growth performance, apparent nutrient digestibility, nitrogen retention and ERE data were tested by means of oneway ANOVA. The differences were tested using Duncan's new multiple range. Intestinal morphometric indices were analysed by fitting a general linear mixed model (GLMM). The GLMM allowed the morphometric indices ( $\mathrm{Vh}, \mathrm{Cd}$ and $\mathrm{Vh} / \mathrm{Cd}$, separately) to depend on three fixed factors (diet, intestinal segment and interaction between diet and intestinal segment) with the animal included as a random effect to account for repeated measurements on the same bird. The interactions between the levels of the fixed factors were evaluated by pairwise comparisons. The histopathological scores were analysed by means of the Kruskal-Wallis test post 
hoc test: Dunn's multiple comparison test). The results were expressed as means with pooled standard errors of the means (SEM). Significance was declared at $p \leq .05$.

\section{3 | RESULTS}

\section{1 | Growth performance}

The dietary treatment increased BW at 12, 25 and 40 days of age ( $p<.001 ; p<.001$ and $p=.018$, respectively) in chickens fed the SDPP diet compared to the other groups (Table 4). During the starter period, the greatest ADG (28.4 g/day versus 22.4 and $23.6 \mathrm{~g} / \mathrm{day}$; $p<.001$ ) and ADFI (33.1 g/day versus 30.5 and $31.5 \mathrm{~g} / \mathrm{day} ; p=.031$ ) were found in chickens fed the SDPP diet compared to those fed the $\mathrm{C}$ and $\mathrm{G}$ ones respectively. Moreover, a lower FCR was found in chickens fed SDPP diet compared to birds fed the $C$ diet (1.16 versus 1.37, respectively; $p<.001)$. During the entire rearing cycle, ADG was higher and FCR was lower in the SDPP group compared to the $\mathrm{C}$ and $\mathrm{G}$ ones.

TAB LE 4 Effects of dietary globin and SDPP on growth performance of broiler chickens $(n=8)$

\begin{tabular}{|c|c|c|c|c|c|}
\hline & C diet & G diet & $\begin{array}{l}\text { SDPP } \\
\text { diet }\end{array}$ & SEM & $\begin{array}{l}p \text { - } \\
\text { value }\end{array}$ \\
\hline \multicolumn{6}{|c|}{ Starter phase (1-12 days) } \\
\hline BW at 1 day, g & 48.6 & 48.8 & 48.7 & 0.11 & .651 \\
\hline BW at 12 days, $g$ & $295^{\mathrm{b}}$ & $309^{\mathrm{b}}$ & $362^{\mathrm{a}}$ & 6.70 & $<.001$ \\
\hline ADG, g/day & $22.4^{\mathrm{b}}$ & $23.6^{\mathrm{b}}$ & $28.4^{a}$ & 0.61 & $<.001$ \\
\hline ADFI, g/day & $30.5^{\mathrm{b}}$ & $31.5^{\mathrm{b}}$ & $33.1^{\mathrm{a}}$ & 0.42 & .031 \\
\hline $\mathrm{FCR}, \mathrm{g} / \mathrm{g}$ & $1.37^{\mathrm{a}}$ & $1.33^{\mathrm{a}}$ & $1.16^{\mathrm{b}}$ & 0.022 & $<.001$ \\
\hline \multicolumn{6}{|c|}{ Grower phase (12-25 days) } \\
\hline BW at 25 days, $g$ & $1144^{\mathrm{b}}$ & $1181^{b}$ & $1264^{a}$ & 15.31 & .001 \\
\hline ADG, g/day & 61.2 & 62.4 & 64.6 & 0.76 & .176 \\
\hline ADFI, g/day & 89.9 & 93.0 & 94.4 & 1.00 & .180 \\
\hline FCR, g/g & 1.47 & 1.49 & 1.46 & 0.017 & .786 \\
\hline \multicolumn{6}{|c|}{ Finisher phase (25-40 days) } \\
\hline BW at 40 days, $g$ & $2416^{b}$ & $2430^{b}$ & $2553^{a}$ & 22.69 & .018 \\
\hline ADG, g/day & 83.9 & 82.4 & 85.9 & 0.81 & .210 \\
\hline ADFI, g/day & 148.2 & 150.7 & 149.0 & 1.43 & .789 \\
\hline FCR, g/g & 1.77 & 1.83 & 1.73 & 0.017 & .075 \\
\hline \multicolumn{6}{|c|}{ Whole period (1-40 days) } \\
\hline ADG, g/day & $59.0^{\mathrm{b}}$ & $59.1^{\mathrm{b}}$ & $62.6^{\mathrm{a}}$ & 0.58 & .010 \\
\hline ADFI, g/day & 95.6 & 97.8 & 98.1 & 0.75 & .336 \\
\hline FCR, g/g & $1.62^{\mathrm{a}}$ & $1.65^{\mathrm{a}}$ & $1.57^{\mathrm{b}}$ & 0.011 & .001 \\
\hline
\end{tabular}

Note: The means with different superscript letters $(a, b)$ within the same row differ significantly $(p<.05)$.

Abbreviations: $A D F I$, average daily feed intake; $A D G$, average daily weight gain; BW, body weight; C, control; FCR, feed conversion ratio; G, globin; SDPP, spray-dried porcine plasma.
TAB LE 5 Effect of dietary globin and SDPP on apparent nutrient digestibility $(\mathrm{aD})$ and nitrogen retention of broiler starter feed $(n=8)$

\begin{tabular}{llllll} 
& C diet & G diet & $\begin{array}{l}\text { SDPP } \\
\text { diet }\end{array}$ & SEM & $\begin{array}{l}\boldsymbol{p} \text { - } \\
\text { value }\end{array}$ \\
$\mathrm{aD}_{\mathrm{CP}}$ & $87.1^{\mathrm{b}}$ & $95.6^{\mathrm{a}}$ & $95.5^{\mathrm{a}}$ & 0.91 & $<.001$ \\
$\mathrm{aD}_{\mathrm{EE}}$ & 95.1 & 95.4 & 95.8 & 0.20 & .462 \\
$\mathrm{~N}$ retention & $68.1^{\mathrm{c}}$ & $73.7^{\mathrm{a}}$ & $70.3^{\mathrm{b}}$ & 0.607 & $<.001$ \\
\hline
\end{tabular}

Note: The means with different superscript letters $(a, b, c)$ within the same row differ significantly $(p<.05)$.

Abbreviations: $\mathrm{C}$, control; $\mathrm{CP}$, crude protein; $\mathrm{EE}$, ether extract; $\mathrm{G}$, globin; $N$ retention, nitrogen retention; SDPP, spray-dried porcine plasma.

\section{2 | Nutrient digestibility}

No significant difference was observed among dietary groups for the digestibility of EE. The digestibility of CP was higher in chickens fed the G and SDPP diets (95.6\% and 95.5\%, respectively) compared to the $\mathrm{C}$ diet (87.1\%) ( $p<.001$; Table 5). Nitrogen retention was highest in the $\mathrm{G}$ diet (73.7\%), followed by the SDPP diet (70.3\%) and significantly lowest in the $\mathrm{C}$ diet $(68.1 \%)(p<.001)$.

\section{3 | Energy retention efficiency}

During the starter phase, the ERE was higher $(p=.004)$ in chickens fed the SDPP diet compared to those with the $C$ and $\mathrm{G}$ diets (36.04 versus 32.43 and $31.67 \%$, respectively; Table 6). Nevertheless, no significant difference among treatments was observed for ERE during the grower-finisher phase (12-40 days of age) and during the overall rearing period (1-40 days of age).

\subsection{Histomorphological investigations}

The dietary inclusion of either SDPP or globin did not influence $(p>.05)$ the gut morphometric indices of birds slaughtered at 12 days or 40 days of age, despite a numerical ( $+6.90 \%$ and $7.40 \%$ ) villus height improvement in SDPP group at 12 and 40 days of age, respectively (Table 7).

Histopathological alterations were observed in all organs regardless from the dietary treatment or the slaughtering age. The dietary

TABLE 6 Effects of dietary globin and SDPP on ERE (\%) of broiler chickens $(n=8)$

\begin{tabular}{|c|c|c|c|c|c|}
\hline & $C$ diet & G diet & $\begin{array}{l}\text { SDPP } \\
\text { diet }\end{array}$ & SEM & $\begin{array}{l}p \text { - } \\
\text { value }\end{array}$ \\
\hline $1-12$ days of age & $32.43^{b}$ & $31.67^{b}$ & $36.04^{a}$ & 0.618 & .004 \\
\hline $12-40$ days of age & 33.66 & 33.83 & 33.51 & 0.392 & .951 \\
\hline $1-40$ days of age & 33.54 & 33.60 & 33.80 & 0.357 & .958 \\
\hline
\end{tabular}

Note: The means with different superscript letters $(a, b)$ within the same row differ significantly $(p<.05)$.

Abbreviations: C, control; ERE, energy retention efficiency; G, globin; SDPP, spray-dried porcine plasma. 
TABLE 7 Effects of dietary globin and SDPP on intestinal morphometric indices in the broiler chickens in relation to the diet and the intestinal segment at 12 and 40 days of age $(n=8)$

\begin{tabular}{|c|c|c|c|c|c|c|c|c|c|c|}
\hline & \multicolumn{3}{|c|}{ Diet (D) } & \multicolumn{3}{|c|}{ Intestinal segment (IS) } & SEM & \multicolumn{3}{|c|}{$p$-value } \\
\hline Vh, mm & 1.16 & 1.19 & 1.24 & $1.74^{\mathrm{a}}$ & $0.99^{\mathrm{b}}$ & $0.86^{\mathrm{b}}$ & 0.080 & .782 & $<.001$ & .359 \\
\hline $\mathrm{Cd}, \mathrm{mm}$ & 0.15 & 0.15 & 0.14 & $0.16^{a}$ & $0.14^{\mathrm{b}}$ & $0.14^{\mathrm{b}}$ & 0.010 & .902 & .023 & .731 \\
\hline $\mathrm{Vh}, \mathrm{mm}$ & 1.48 & 1.55 & 1.59 & $2.19^{a}$ & $1.43^{b}$ & $0.99^{c}$ & 0.100 & .768 & $<.001$ & .804 \\
\hline $\mathrm{Cd}, \mathrm{mm}$ & 0.17 & 0.17 & 0.19 & $0.23^{\mathrm{a}}$ & $0.16^{\mathrm{b}}$ & $0.14^{b}$ & 0.010 & .587 & $<.001$ & .380 \\
\hline $\mathrm{Vh} / \mathrm{Cd}$ & 8.73 & 9.00 & 8.51 & $10.20^{\mathrm{a}}$ & $9.08^{a}$ & $6.96^{\mathrm{b}}$ & 0.540 & .833 & $<.001$ & .474 \\
\hline
\end{tabular}

Note: The means with different superscript letters ( $a, b$ and $c$ ) within the same row per fixed effect (i.e. diet, intestinal segment) differ significantly $(p<.05)$.

Abbreviations: C, control; Cd, crypt depth; G, globin; SDPP, spray-dried porcine plasma; Vh, villus height; Vh/Cd, villus height to crypt depth ratio.

inclusion of either SDPP or globin did not affect the severity of the histopathological alterations ( $p>.05$, Table 8 ). In details, the liver showed multifocal to diffuse, mild-to-severe vacuolar degeneration of the hepatocytes, as well as focal to multifocal, mild-to-moderate, interstitial and/or periportal lymphoid tissue activation. Multifocal, mild-to-severe white pulp hyperplasia or depletion was observed in the spleen. Finally, the bursa of Fabricius showed multifocal to diffuse, mild-to-severe follicular depletion, with or without intrafollicular cysts, fibrous tissue deposition and/or follicular atrophy.

\section{DISCUSSION}

Processed protein sources, such as soybean protein isolate or gluten protein isolate, SDPP and globin, are valuable protein sources that can be used in poultry diets as high-nutritive feedstuffs (Peisker, 2001; Torrallardona, 2010). SDPP was found to positively influence poultry performance, digestibility and health during stressful production conditions (Campbell et al., 2003, 2004; Campbell, Russell, Crenshaw, \& Koehnk, 2006). Therefore, the aim of this study was to assess the intestinal mechanisms, namely digestive efficiency and gut morphology, involved in the improvement of broiler performance fed diets supplemented with SPDD or globin.

In the current study, supplementation with globin did not lead to improved growth performance, unlike observations of previous studies (Arnouts \& Lippens, 2006; Dabbou et al., 2019). Together with improved performance, Dabbou et al. (2019) found higher $\mathrm{aD}_{\mathrm{EE}}$ and nitrogen retention but similar $\mathrm{aD}_{\mathrm{CP}}$ in the globin $(0.05 \%)$ group compared to the control group during the starter period. Also, Upadhaya, Lee, Jung, and Kim (2018) observed a higher $\mathrm{aD}_{\mathrm{EE}}$ but
TABLE 8 Histopathological scores ${ }^{a}$ of organs of the broiler chickens $(n=8)$

\begin{tabular}{|c|c|c|c|c|c|}
\hline & C diet & G diet & SDPP diet & SEM & $\begin{array}{l}p \text { - } \\
\text { value }\end{array}$ \\
\hline \multicolumn{6}{|l|}{12 days of age } \\
\hline \multicolumn{6}{|l|}{ Liver } \\
\hline Degenerative changes & 0.25 & 1.00 & 0.56 & 0.162 & 197 \\
\hline Lymphoid tissue activation & 0.75 & 0.63 & 0.63 & 0.098 & .836 \\
\hline Spleen & 0.25 & 0.38 & 0.25 & 0.127 & .532 \\
\hline Bursa of Fabricius & 1.06 & 1.00 & 1.00 & 0.136 & .944 \\
\hline \multicolumn{6}{|l|}{40 days of age } \\
\hline \multicolumn{6}{|l|}{ Liver } \\
\hline Degenerative changes & 1.88 & 1.75 & 1.31 & 0.187 & .294 \\
\hline Lymphoid tissue activation & 1.75 & 1.25 & 1.13 & 0.118 & .068 \\
\hline Spleen & 0.25 & 1.38 & 0.25 & 0.207 & .186 \\
\hline Bursa of Fabricius & 1.75 & 2.25 & 1.44 & 0.180 & .112 \\
\hline
\end{tabular}

Abbreviations: C, control; G, globin; SDPP, spray-dried porcine plasma.

${ }^{\mathrm{a}}$ The data are expressed as the mean of the scores $(0=$ absence of alterations; $1=$ mild alterations; 2 = moderate alterations; and 3 = severe alterations). 
a similar $\mathrm{aD}_{\mathrm{CP}}$ in broilers fed a diet supplemented with a commercial blend of emulsifiers ( 0.05 up to $0.10 \%$ supplementation). On the contrary, we observed that globin supplementation did not affect $\mathrm{aD}_{\mathrm{EE}}$ but enhanced $a \mathrm{D}_{\mathrm{CP}}$ and nitrogen retention during the starter period. However, this improvement was not associated with higher energy retention efficiency. Neither gut morphology nor the development and the severity of the organ histopathological findings were influenced by globin supplementation, and to our knowledge, no previous studies are available for any comparison. Nevertheless, the absence of a difference in histopathological scores among birds fed different diets reliably rules out a role of this feed additive in the occurrence of the observed alterations. Probably, the very good bird's performance, as revealed by the low mortality and high body weight, could be associated with the lack of the potential positive effects of globin, previously reported by Dabbou et al. (2019).

On the contrary, dietary SDPP inclusion positively influenced the growth performance of birds, especially BW, consistently with previous results (Campbell et al., 2006). In fact, higher BW and improved FCR during the starter phase (1-21 days of age) were reported in broilers fed $0.5 \%$ to $1.5 \%$ SDPP (Henn et al., 2013), $2 \%$ SDPP (Walters, Jasek, Campbell, Coufal, \& Lee, 2019) and up to 4\% SDPP (Jamroz et al., 2012). Other studies also showed that the enhancement of growth performance persisted from 28 days to 41 days (Walters et al., 2019) or during the whole growth period (Beski, Swick, \& lji, 2015b, 2015c). These positive results could be associated with the high digestibility of SDPP that likely contributed to improve chickens performance (Beski, Swick, \& lji, 2015b; Torrallardona, Conde, Badiola, Polo, \& Brufau, 2003). In the present study, higher protein digestibility and nitrogen retention in birds fed SDPP, as compared with $\mathrm{C}$ group, reflect a lower nitrogen excretion in SDPP group during the starter period. Currently, there is no literature concerning the effects of SDPP on the total tract apparent digestibility coefficients of broiler chickens, which could support differences in performance. However, no effects of SDPP supplementation in broiler diets were previously reported on ileal digestibility of DM, CP and GE (Beski et al., 2015b; Jamroz et al., 2012), despite weak differences in digestibility of EE (Jamroz et al., 2012). No effects of different inclusion levels of SDPP have been reported for the total apparent digestibility coefficient of $\mathrm{CP}$ in weanling pigs by Sun, Ma, Li, and Ji, (2009), whereas other authors found higher DM and CP digestibility for SDPP compared to other protein sources in young pigs (Pendergraft, Hancock, Hines, Mills, \& Burnham, 1993).

Energy retention efficiency provides a further indication of how efficiently broiler chickens utilize dietary energy. The higher ERE observed in the SDPP group during the starter phase, compared to the $C$ and $G$ groups, suggests a more efficient energy utilization in the former group compared to the latter ones. This could be potentially attributed to the higher nitrogen retention associated with SDPP supplementation.

On the other hand, in the present study, SDPP supplementation did not affect the gut morphology of the broiler chickens nor the development or the severity of the organ histopathological traits. However, a numerical villus height improvement in SDPP group was observed at 12 and 40 days of age. The magnitude of this increment $(+6.90 \%$ and $+7.40 \%$ respectively) is similar or even higher than that reported by other authors (Beski, Swick, \& lji, 2015c; Jamroz et al., 2011, 2012; King et al., 2005) when comparing similar age, intestinal segment and SDPP inclusion level. The lack of statistical significance in our study could be associated with a high variability among the collected samples. Thus, we may hypothesize that the improved growth performance in chickens fed SDPP diets could also be related to changes in gut morphology, even if this observation needs further investigation to be confirmed.

Finally, regardless of dietary treatment, we confirmed that the chickens' duodenum had greater development in relation to the other gut segments. Indeed, the identification of a proximodistal decreasing gradient of the morphometric indices from the duodenum to the ileum has previously been demonstrated to represent the physiological gut development (Forder, Howarth, Tivey, \& Hughes, 2007; lji, Saki, \& Tivey, 2001; de Verdal et al., 2010).

\section{5 | CONCLUSIONS}

Our findings and literature data report an improvement of growth performance, total tract $\mathrm{aD}$ of protein, nitrogen retention and $\mathrm{ERE}$ during the starter period in broilers fed SDPP and to a lower extent, globin diets. Nevertheless, improved performance and digestibility traits could not be explained by significant changes at the level of gut morphology, even if promising results have been observed. Under the normal rearing conditions of this experiment, SDPP has greatest potential as a feed ingredient for broiler chickens during the starter period, with positive impact on production performance and without negative effects on gut health.

\section{ACKNOWLEDGEMENTS}

The authors are grateful to Dr. Oreste Massimino, Mr. Roberto Borgogno and Mrs. Marilena Falcetti, "O.R.A. Agricola Srl" (Cherasco, CN, Italy), Dr. Piero Gaidano (Mangimificio Fratelli Borello, Bra, CN, Italy), Dr. Andrea Dama, Mr. Dario Sola, Mr. Mario Colombano and Mrs. Alessandra Sereno (University of Turin, Italy) for technical support. The study was supported by VEOS, Belgium under Grant (SCHA_CONTR_FIN_18_01).

\section{CONFLICT OF INTEREST}

The authors have no conflict of interest.

\section{ANIMAL WELFARE STATEMENT}

The experimental protocol was approved by the Ethical Committee for Animal Experimentation of the DVS (Protocol n. 420078). All animals were handled in respect to the principles stated by the EC Directive 86/609/EEC regarding the protection of animals used for experimental and other scientific purposes.

\section{ORCID}

Sihem Dabbou iD https://orcid.org/0000-0002-3525-1614 


\section{Angela Trocino iD https://orcid.org/0000-0001-9045-6156 Gerolamo Xiccato iD https://orcid.org/0000-0003-4572-3635 Joana Nery iD https://orcid.org/0000-0002-6941-1305 Josefa Madrid (iD https://orcid.org/0000-0001-6255-9078 Silvia Martinez iD https://orcid.org/0000-0002-1350-0886 Fuensanta Hernández (iD https://orcid.org/0000-0002-8795-416X Isabelle D. Kalmar (iD https://orcid.org/0000-0001-8654-8517 Maria Teresa Capucchio iD https://orcid. org/0000-0002-1068-0551 \\ Elena Colombino iD https://orcid.org/0000-0002-6371-2000 Ilaria Biasato iD https://orcid.org/0000-0002-8855-4248 Lucia Bailoni iD https://orcid.org/0000-0003-3027-2288 Laura Gasco iD https://orcid.org/0000-0002-1829-7936 Cecilia Mugnai (iD https://orcid.org/0000-0003-0172-4978 Achille Schiavone iD https://orcid.org/0000-0002-8011-6999}

\section{REFERENCES}

AOAC (2005). Official method of Analysis, $18^{\text {th }}$ ed. Washington, DC: Association of Official Analytical Chemists.

Arnouts, S., \& Lippens, M. (2006). The effect of globin, a water-soluble emulsifier, on broiler performance. In Proc. $12^{\text {th }}$ European poultry conference (pp. 199). Verona, IT. 10-14 September 2006.

Aviagen (2014). Ross 708 Broiler. Available from: Broiler Performance Objectives. http://en.aviagen.com/assets/Tech_left/Ross_Broiler/ Ross-708-Broiler-PO-2014-EN.pdf

Beski, S. S. M., Swick, R. A., \& lji, P. A. (2015a). Specialized protein products in broiler chiken nutrition: A review. Animal Nutrition, 1, 47-53. https://doi.org/10.1016/j.aninu.2015.05.005

Beski, S. S. M., Swick, R. A., \& lji, P. A. (2015b). The effect of the concentration and feeding duration of spray-dried plasma protein on growth performance, digestive enzyme activities, nutrient digestibility and intestinal mucosal development of broiler chickens. Animal Production Science, 56, 1820-1827. https://doi. org/10.1071/AN141021

Beski, S. S. M., Swick, R. A., \& lji, P. A. (2015c). Subsequent growth performance and digestive physiology of broilers fed on starter diets containing spray-dried porcine plasma as a substitute for meat meal. British Poultry Science, 56, 559-568. https://doi.org/10.1080/00071 668.2015.1068429

Biasato, I., Gasco, L., De Marco, M., Renna, M., Rotolo, L., Dabbou, S., ... Schiavone, A. (2017). Effects of yellow mealworm larvae (Tenebrio molitor) inclusion in diets for female broiler chickens: Implications for animal health and gut histology. Animal Feed Science and Technology, 234, 253-263. https://doi.org/10.1016/j.anifeedsci.2017.09.014

BOE (2000). Métodos oficiales de análisis de piensos o alimentos para animales y sus primeras materias. Boletín Oficial Del Estado, 41, 7211-7215.

Boyer, P. E., D'Costa, S., Edwards, L. L., Milloway, M., Susick, E., Borst, L. B., ... Moeser, A. J. (2015). Early-life dietary spray-dried plasma influences immunological and intestinal injury responses to later-life Salmonella typhimurium challenge. British Journal of Nutrition, 113, 783-793. https://doi.org/10.1017/S000711451400422X

Campbell, J., Quigley, J., \& Russell, L. (2004). Impact of spray-dried bovine serum and environment on turkey performance. Poultry Science, 83, 1683-1687. https://doi.org/10.1093/ps/83.10.1683

Campbell, J., Quigley, J., Russell, L., \& Kidd, M. (2003). Effect of spraydried bovine serum on intake, health, and growth of broilers housed in different environments. Journal of Animal Science, 81, 2776-2782. https://doi.org/10.2527/2003.81112776x
Campbell, J., Russell, L., Crenshaw, J., \& Koehnk, H. (2006). Effect of spray-dried plasma form and duration of feeding on broiler performance during natural necrotic enteritis exposure. Journal of Applied Poultry Researc, 15, 584-591. https://doi.org/10.1093/japr/15.4.584

Coffey, R. D., \& Cromwell, G. L. (2001). Reviews-Use of spray-dried animal plasma in diets for weanling pigs. Pig News and Information, 22, 39-48.

Dabbou, S., Gai, F., Biasato, I., Capucchio, M. T., Biasibetti, E., Dezzutto, D., ... Schiavone, A. (2018). Black soldier fly defatted meal as a dietary protein source for broiler chickens: Effects on growth performance, blood traits, gut morphology and histological features. Journal of Animal Science and Biotechnolology, 9, 49. https://doi.org/10.1186/ s40104-018-0266-9

Dabbou, S., Schiavone, A., Gai, F., Martinez, M., Madrid, J., Hernandez, F., ... Nery, J. (2019). Effect of dietary globin, a natural emulsifier, on the growth performance and digestive efficiency of broiler chickens. Italian Journal of Animal Science, 18(1), 530-537. https://doi. org/10.1080/1828051X.2018.1547127

de Verdal, H., Mignon-Grasteau, S., Jeulin, C., Le Bihan-Duval, E., Leconte, M., Mallet, S., ...Narcy, A. (2010). Digestive tract measurements and histological adaptation in broiler lines divergently selected for digestive efficiency. Poultry Science, 89, 1955-1961. https://doi. org/10.3382/ps.2010-813

Fatufe, A. A., Timmler, R., \& Rodehutscord, M. (2004). Response to lysine intake in composition of body weight gain and efficiency of lysine utilization of growing male chickens from two genotypes. Poultry Science, 83, 1314-1324. https://doi.org/10.1093/ps/83.8.1314

Forder, R., Howarth, G., Tivey, D., \& Hughes, R. (2007). Bacterial modulation of small intestinal goblet cells and mucin composition during early posthatch development of poultry. Poultry Science, 86(11), 2396-2403. https://doi.org/10.3382/ps.2007-00222

Henn, J. D., Bockor, L., Vieira, M. S., Ribeiro, A. M. L., Kessler, A. M., Albino, L., ... Rangel, L. F. S. (2013). Inclusion of porcine spray-dried plasma in broiler diets. The Journal of Applied Poultry Research, 22, 229-237. https://doi.org/10.3382/japr.2012-00613

Iji, P. A., Saki, A., \& Tivey, D. R. (2001). Body and intestinal growth of broiler chicks on a commercial starter diet. 1. Intestinal weight and mucosal development. British Poultry Science, 42, 505-513. https:// doi.org/10.1080/00071660120073151

Jamroz, D., Wiliczkiewicz, A., Orda, J., Kuryszko, J., \& Stefaniak, T. (2012). Use of spray-dried porcine blood by-products in diets for young chickens. Journal of Animal Physiology and Animal Nutrition, 96, 319333. https://doi.org/10.1111/jpn.2012.96.issue-2

Jamroz, D., Wiliczkiewicz, A., Orda, J., Skorupińska, J., Słupczyńska, M., \& Kuryszko, J. (2011). Chemical composition and biological value of spray dried porcine blood byproducts and bone protein hydrolysate for young chickens. British Poultry Science, 52, 589-605. https://doi. org/10.1080/00071668.2011.610298

Kaczmarek, S. A., Bochenek, M., Samuelsson, A. C., \& Rutkowski, A. (2015). Effects of glyceryl polyethylene glycol ricinoleate on nutrient utilisation and performance of broiler chickens. Archives of Animal Nutrition, 69, 285-296. https://doi.org/10.1080/17450 39X.2015.1061722

King, M., Ravindran, V., Morel, P., Thomas, D., Birtles, M., \& Pluske, J. (2005). Effects of spray-dried colostrum and plasmas on the performance and gut morphology of broiler chickens. Australian Journal of Agricultural Research, 56, 811-817. https://doi.org/10.1071/AR04324

Laudadio, V., Passantino, L., Perillo, A., Lopresti, G., Passantino, A., Khan, R. U., \& Tufarelli, V. (2012). Productive performance and histological features of intestinal mucosa of broiler chickens fed different dietary protein levels. Poultry Science, 91, 265-270. https://doi.org/10.3382/ ps.2011-01675

Madrid, J., Martínez, S., López, C., Orengo, J., López, M. J., \& Hernández, F. (2013). Effects of low protein diets on growth performance, 
carcass traits and ammonia emission of barrows and gilts. Animal Production Science, 53, 146-153. https://doi.org/10.1071/AN12067

Marquardt, R. R. (1983). A simple spectrophotometric method for the direct determination of uric acid in avian excreta. Poultry Science, 62 2106-2108. https://doi.org/10.3382/ps.0622106

Müller, L. K. F., Paiano, D., Gugel, J., Lorenzetti, W. R., Santurio, J. M. Tavernari, F., ... Da Silva, A. S. (2018). Post-weaning piglets fed with different levels of fungal mycotoxins and spray-dried porcine plasma have improved weight gain, feed intake and reduced diarrhea incidence. Microbial Pathogenesis, 117, 259-264. https://doi. org/10.1016/j.micpath.2018.02.035

Myers, W. D., Ludden, P. A., Nayigihugu, V., \& Hess, B. W. (2004). A procedure for the preparation and quantitative analysis of samples for titanium dioxide. Journal of Animal Science, 82, 179-183. https://doi. org/10.2527/2004.821179x

Peisker, M. (2001). Manufacturing of soy protein concentrate for animal nutrition. Cahiers Options Méditerranéennes, 54, 103-107. http:// om.ciheam.org/article.php?IDPDF=1600017

Pendergraft, J. S., Hancock, J. D., Hines, R. H., Mills, C. G., \& Burnham, L. L. (1993). Effects of wheat gluten and plasma protein on growth performance and digestibility of nutrients in nursery pigs. In Swine Day Report (pp. 58-62). Manhattan, KS: Kansas State University, Agricultural experiment Station and Cooperative Extension Service (ed).

Pérez-Bosque, A., Polo, J., \& Torrallardona, D. (2016). Spray dried plasma as an alternative to antibiotics in piglet feeds, mode of action and biosafety. Porcine Health Management, 2, 16. https://doi.org/10.1186/ s40813-016-0034-1

Qaisrani, S. N., Moquet, P. C., van Krimpen, M. M., Kwakkel, R. P., Verstegen, M. W., \& Hendriks, W. H. (2014). Protein source and dietary structure influence growth performance, gut morphology, and hind gut fermentation characteristics in broilers. Poultry Science, 93, 3053-3064. https://doi.org/10.3382/ps.2014-04091

Stein, H. (1996). The effects of adding spray dried plasma protein and spray dried blood cells to starter diets for pigs. In: Proc. Anais do Simposio LatinoAmericano de nutricao de suinos e aves (pp. 70-86). Campinas, Brazil: Colégio Brasileiro de Nutrição Animal (CBNA)(ed).

Sun, Z., Ma, Q., Li, Z., \& Ji, C. (2009). Effect of partial substitution of dietary spray-dried porcine plasma or fishmeal with soybean and shrimp protein hydrolysate on growth performance, nutrient digestibility and serum biochemical parameters of weanling piglets. Asian Australasian Journal of Animal Science, 22, 1032-1037.

Thomson, J. E., Jones, E. E., \& Eisen, E. J. (1995). Effect of spray-dried porcine plasma protein on growth traits and nitrogen and energy balance in mice. Journal of Animal Science, 73, 2340-2346. https://doi. org/10.2527/1995.7382340x

Torrallardona, D. (2010). Spray dried animal plasma as an alternative to antibiotics in weanling pigs. A review. Asian-Australasian Journal of Animal Science, 23, 131-148.

Torrallardona, D., Conde, M. R., Badiola, I., Polo, J., \& Brufau, J. (2003). Effect of fishmeal replacement with spray-dried animal plasma and colistin on intestinal structure, intestinal microbiology, and performance of weanling pigs challenged with Escherichia coli K991. Journal of Animal Science, 81, 1220-1226. https://doi. org/10.2527/2003.8151220x

Upadhaya, S. D., Lee, J. S., Jung, K. J., \& Kim, I. H. (2018). Influence of emulsifier blends having different hydrophilic-lipophilic balance value on growth performance, nutrient digestibility, serum lipid profiles, and meat quality of broilers. Poultry Science, 97, 255-261. https://doi.org/10.3382/ps/pex303

van Djik, A. J., Everts, H., Nabuurs, M. J. A., Margry, R. J. C. F., \& Beynen, A. (2001). Growth performance of weanling pigs fed spray-dried animal plasma: A review. Livestock Production Science, 68, 263-274. https://doi.org/10.1016/S0301-6226(00)00229-3

Walters, H. G., Jasek, A., Campbell, J. M., Coufal, C., \& Lee, J. T. (2019). Evaluation of spray-dried plasma in broiler diets with or without bacitracin methylene disalicylate. The Journal of Applied Poultry Research, 28, 364-373. https://doi.org/10.3382/japr/pfy080

How to cite this article: Dabbou S, Trocino A, Xiccato G, et al. The effect of dietary supplementation with globin and spray-dried porcine plasma on performance, digestibility and histomorphological traits in broiler chickens. J Anim Physiol Anim Nutr. 2020;00:1-10. https://doi.org/10.1111/jpn.13356 